\title{
KESTABILAN TEBING BATAS UNTUK MENERAPKAN METODE PENAMBANGAN GURDI PADA CADANGAN BATUBARA MARGINAL DI PASER, KALIMANTAN TIMUR
}

\author{
The Application of Highwall Stability for Auger Mining Method on \\ Marginal Coal Reserves at Paser, East Kalimantan
}

\author{
NOVA FATHONA ${ }^{1}$ dan ZULFAHMI ${ }^{2}$ \\ ${ }^{1}$ Fakultas Teknik Pertambangan, Universitas Sriwijaya, Sumatera Selatan \\ Jalan Srijaya Negara Bukit Besar, Bukit Lama, Ilir Bar. I, \\ Kota Palembang, Sumatera Selatan 30128 \\ e-mail: novafathona@gmail.com \\ 2 Puslitbang Teknologi Mineral dan Batubara \\ Jalan Jenderal Sudirman 623 Bandung 40211
}

\begin{abstract}
Penambangan gurdi adalah metode yang sesuai untuk mengambil bahan galian pada dinding-dinding tebing batas dan dioperasikan tanpa melakukan pengupasan tanah penutup. Pada kasus ini, kestabilan batuan adalah aspek yang penting untuk dikaji. Pada studi ini dilakukan pemodelan numerik dengan metode elemen hingga menggunakan perangkat lunak Ansys untuk menemukan kondisi yang stabil dan recovery penambangan yang optimum. Lubang bor gurdi dibuat dengan variasi kedalaman 50, 80, 120, dan 200 m, sedangkan geometri penambangan gurdi dirancang dengan spasi antar panel sebesar $0,5 \mathrm{~m}$, barrier pillar $3 \mathrm{~m}$, jumlah panel 5, dan kemiringan bor penambangan gurdi sebesar $6^{\circ}$ menggunakan kepala pemotong (cutter head) berdiameter 8 m. Hasil kajian menunjukkan bahwa metode ini aman dan baik untuk diterapkan dilihat dari hasil analisis faktor keamanan dan deformasi yang terjadi setelah disimulasikan lubang gurdi pada tebing batas untuk nilai faktor keamanan menunjukkan nilai yang stabil. Kedalaman 50 m, nilai faktor keamanannya sebesar 1,9804; kedalaman $80 \mathrm{~m}$ nilai faktor keamanannya sebesar 1,8603, kedalaman $120 \mathrm{~m}$ nilai faktor keamanannya sebesar 1,8279, dan kedalaman $200 \mathrm{~m}$ nilai faktor keamanannya sebesar 1,6623. Total deformasi menunjukkan nilai yang tidak besar. Pada kedalaman $50 \mathrm{~m}$, total deformasi maksimal sebesar 0,013438 m, kedalaman $80 \mathrm{~m}$ total deformasi maksimal sebesar $0,013436 \mathrm{~m}$, kedalaman $120 \mathrm{~m}$ total deformasi maksimal sebesar 0,013520 m, dan kedalaman $200 \mathrm{~m}$ total deformasi maksimal sebesar 0,013883 m.
\end{abstract}

Kata Kunci: penambangan gurdi, faktor keamanan, deformasi.

\begin{abstract}
Auger mining is a suitable method for extracting the material deposit on the final highwall and is operated without conducting overburden stripping. In this case, rock stability is an important aspect to study. In this study, numerical modeling with finite element method was used to find stable conditions and optimize the mining recovery by using Ansys software. Auger drill holes made with depths of 50, 80, 120, and 200 meters. Then the geometry of auger mining designed with spacing between the panels is 0.5 meter, barrier pillar 3 meters, the number of panels is 5, and slope of drill auger mining is 60 and the diameter of the cutter head is $1.8 \mathrm{~m}$. Results of the study indicate that the auger mining method is safe and good to be applied as seen from the results of safety factor analysis and deformation that occurs after the simulated auger holes in the highwall for the value of the safety factor indicates a stable value. For the depth of 50 meters, the value of safety factor is 1.9804, the depth of 80 meters, safety factors is 1.8603 , the depth value of 120 meters, the safety factor is 1.8279 . For 200-m depth
\end{abstract}


value, the safety factor is 1.6623; The total value of deformation suggests that the value is not big. For the depth of 50 meters, the total maximum deformation is 0.013438 meters, and a depth of 80 meters the total maximum deformation is 0.013436 meters, while at depth of 120 meters the total maximum deformation is 0.013520 meters and a depth of 200 meters, the total maximum deformation is 0.013883 meters.

Keywords: auger mining, safety factor, deformation.

\section{PENDAHULUAN}

Batubara adalah sumber energi yang memiliki cadangan berlimpah. Berdasarkan data Laporan Akuntabilitas Kinerja Instansi Pemerintah Kementerian Energi Sumber Daya Mineral (Lakip KESDM) Republik Indonesia tahun 2016, cadangan batubara di Indonesia mencapai 28.457,29 juta ton (Direktorat Jenderal Mineral dan Batubara, 2017). Sehubungan dengan hal ini, industri pertambangan harus memilih metode yang kreatif dalam upaya pengusahaannya. Metode tambang terbuka sampai saat ini masih dianggap sebagai metode yang lebih menguntungkan dibandingkan dengan metode tambang bawah tanah. Namun, metode tambang terbuka tentu akan mencapai batas akhir penggalian yang ekonomis atau pit limit, seiring dengan kedalaman penggalian. Kondisi yang memburuk pada tambang terbuka setiap tahunnya disebabkan oleh terlalu tingginya stripping ratio, mendekati rasio ekonomi, peraturan perlindungan lingkungan, dan infrastruktur lahan yang buruk untuk penambangan batubara (Lin, 2014). Hal ini yang menjadi sebab banyak perusahaan tambang terbuka berhenti beroperasi sehingga batubara yang berada pada final highwall dianggap sebagai batubara sisa (marginal resource) yang tidak dapat diambil dengan metode tambang terbuka.

Salah satu tambang batubara seperti ini berada di wilayah Paser, Kalimantan Timur, telah mencapai batas akhir penambangan dengan open pit, sedangkan cadangan yang tersisa masih cukup banyak. Berdasarkan Keputusan Menteri ESDM No. 1827, tentang Pedoman Pelaksanaan Kaidah Penambangan yang Baik, menyebutkan bahwa setiap perusahaan tambang wajib melaporkan rencana pengelolaan sisa cadangan yang ada di wilayahnya sebagai bagian dari konservasi. Permasalahan tersebut menjadi latar belakang penulis dalam mengkaji metode alternatif penambangan menggunakan metode gurdi untuk cadangan batubara marginal yang berada pada lereng tebing batas (final highwall).

Studi ini bertujuan untuk mengetahui seberapa besar geometri lubang bukaan penambangan gurdi pada lereng tebing batas untuk tambang batubara marginal yang masih aman untuk ditambang; menentukan faktor keamanan pada lereng tebing atas untuk tambang batubara marginal setelah penambangan gurdi diterapkan pada lereng tersebut; dan menganalisis hasil deformasi pada lereng tebing batas untuk tambang batubara marginal setelah penerapan metode penambangan gurdi pada lereng.

\section{METODE}

Studi ini diawali dengan kajian pustaka, evaluasi data dan parameter yang dibutuhkan oleh perangkat lunak, input data, pemodelan dan analisis hasil pemodelan. Alur kegiatan penelitian dapat dilihat pada Gambar 1 . Pembuatan model awal menggunakan software AutoCad untuk mengubah model desain dari polyline menjadi $3 D$ solid.

Selanjutnya dari geometri model $3 D$ solid AutoCad, dikonversi menjadi format ansys. Langkah selanjutnya dilakukan analisis faktor keamanan dan total deformasi model berbasis finite element. Data hasil FEM kemudian dievaluasi dan divalidasi untuk dianalisis. Pengolahan data dan analisis data secara garis besar meliputi:

a. Mengkaji hasil uji laboratorium yang akan menghasilkan parameter berupa data sifat fisik dan mekanik batuan, yang nantinya akan menjadi engineering data untuk parameter input pada perangkat lunak ansys;

b. Mengkaji dan mengimpor database penampang $\mathrm{F}-\mathrm{F}^{\prime}$ berupa solid properties dengan perangkat lunak Autocad untuk menerjemahkan tipe file .dwg ke pemodelan 3D lereng tebing batas dengan perangkat lunak ansys;

c. Membuat geometri penambangan gurdi sesuai dengan rancangan simulasi yang 
akan dibuat dan melakukan validasi model;

d. Melakukan proses meshing sebagai program komputerisasi pada perangkat lunak ansys;

e. Memasukkan parameter data operasional pada model dan melakukan proses solver;

f. Mengkaji faktor keamanan (FK) dan total deformasi pada model 3D desain tebing batas batubara marginal penerapan penambangan gurdi pada sumuran $A$ section $\mathrm{F}^{-F^{\prime}}$ section $1 \mathrm{~F} 1$.

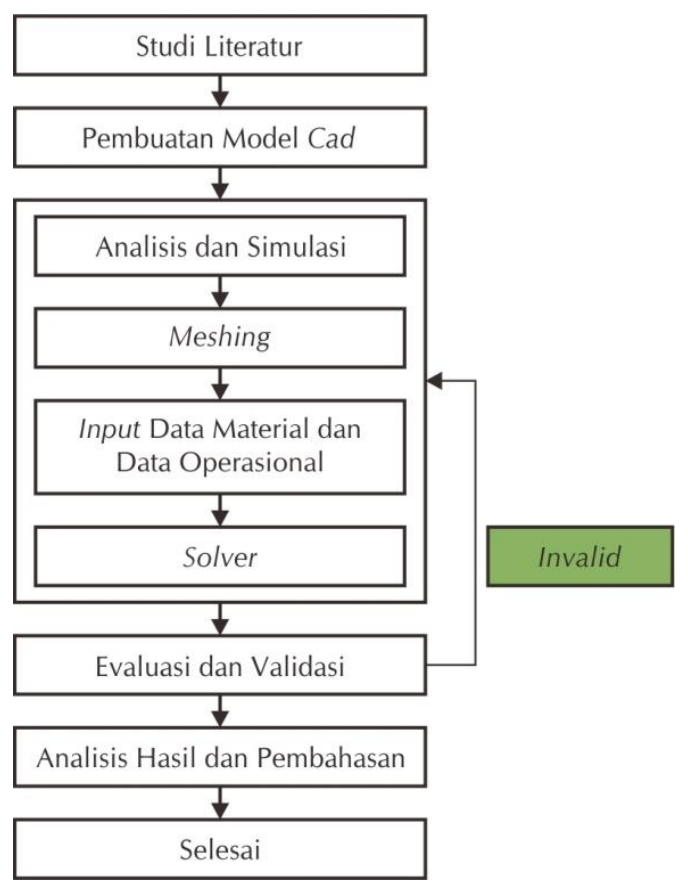

Gambar 1. Bagan alir metodologi penelitian
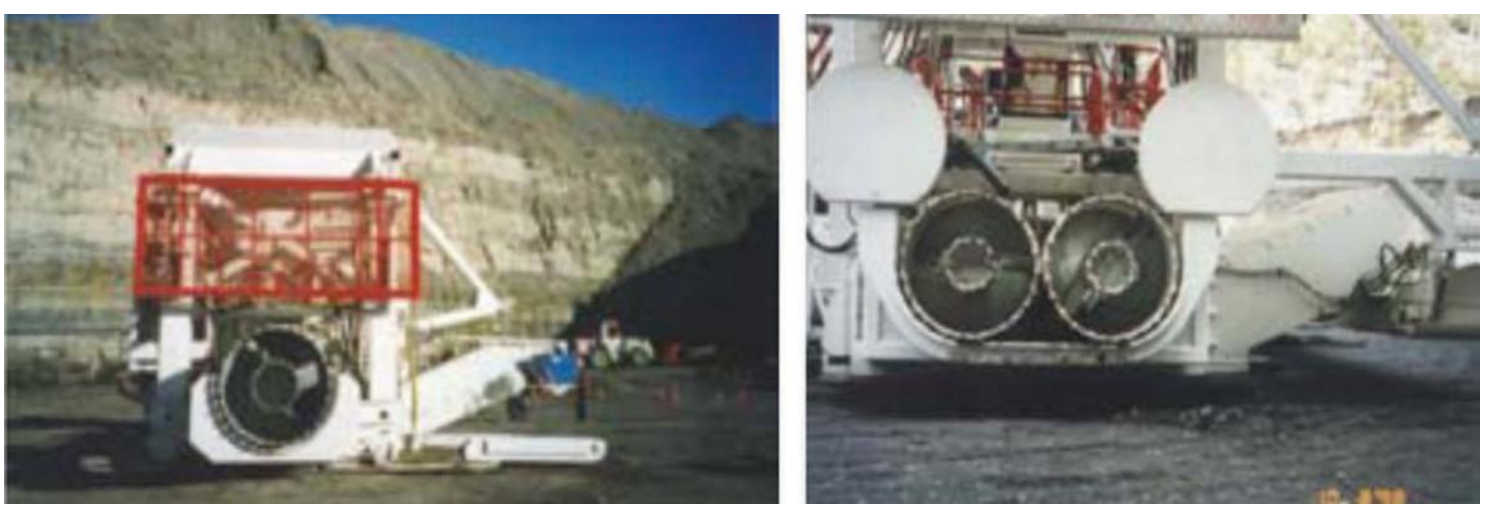

Gambar 2. Mesin gurdi tunggal dan ganda (Porathur $d k k ., 2017$ )

\section{Penambangan Gurdi}

Penambangan gurdi adalah metode penambangan alternatif yang tepat untuk mengambil batubara marginal pada lereng tebing batas dan sudah mencapai batas optimum penambangan dengan cara open pit.

Proses penambangan mencakup kegiatan pengambilan batubara dengan bor spiral, kemudian dengan menggunakan chain conveyor atau belt conveyor dan elevating conveyor dipindahkan ke lokasi penumpukan batubara (Caterpillar, 2009). Tebing batas adalah lereng terjal yang arah kemiringan lerengnya berlawanan dengan arah kemiringan (dip) perlapisan batubara (Swana, Muslim dan Sophian, 2012). Metode ini mengambil batubara dari lapisan yang relatif horizontal mulai dari lereng sampai kedalaman tertentu yang mampu diambil oleh bor gurdi (Dougall, 2010). Penerapan sistem penambangan gurdi sangat sederhana dan dapat menggali hingga kedalaman lebih dari $100 \mathrm{~m}$ dengan diameter lubang 0,5 m atau lebih (Sasaoka, Shimada, dkk., 2015).

Beberapa model Gurdi sudah dikembangkan di antaranya model gurdi tunggal dan ganda (Gambar 2). Selain itu mesin gurdi juga dilengkapi dengan system ban atau rantai berjalan (Gambar 3) untuk memindahkan batubara dari dalam tambang menuju areal penumpukan batubara. 


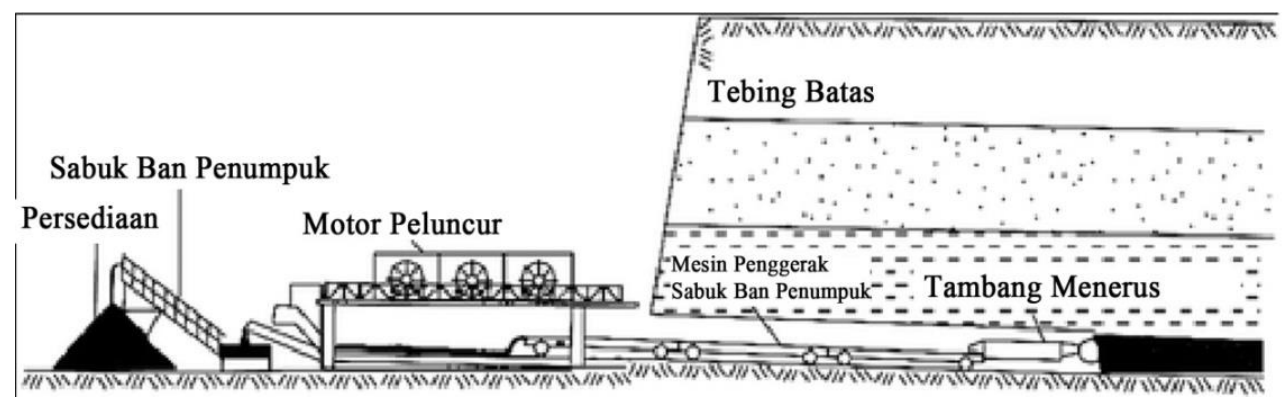

Gambar 3. Sistem ban atau rantai berjalan untuk memindahkan batubara (Porathur $d k k ., 2017$ )

Bentuk dan ukuran pada penambangan gurdi menjadi bahasan utama sebelum melakukan desain lubang bukaan gurdi (auger holes). Konfigurasi lubang gurdi bergantung pada faktor keamanan untuk tiap area tambang dan akan menghasilkan recovery yang berbeda pula (Lukhele, 2002). Gambar 4 menunjukkan contoh desain lubang penambangan gurdi dan Gambar 5 adalah aplikasi penambangan gurdi di Rietspruit Mine Services (Pty) Ltd.

Ketika proses penambangan dimulai yang dikembangkan dari lereng open pit, desain panel dan keamanan pilar seperti boundary pillar dan pillar antar panel di area transisi mempunyai pengaruh yang besar terhadap stabilitas tebing batas serta jumlah sumberdaya recovery di sekitar final highwall. Jika ukuran pilar dan panel tidak memadai, sangat memungkinkan terjadi ketidakstabilan lereng atau longsor karena kurangnya penahan untuk tebing batas. Di sisi lain, jika pilar berukuran besar akan mempengaruhi recovery. Oleh karena itu, dalam perencanaan, model sangat penting untuk diperhatikan (Sasaoka, Hamanaka, dkk., 2015).

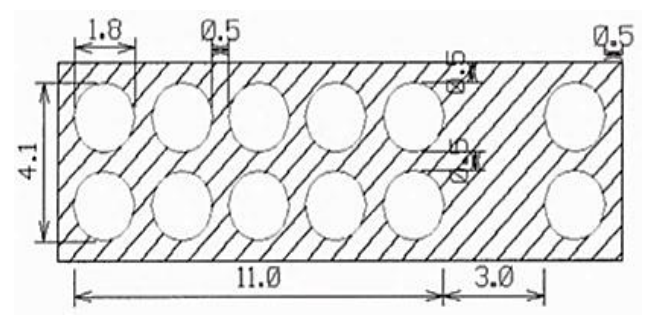

Gambar 4. Desain lubang penambangan gurdi (Lukhele, 2002)

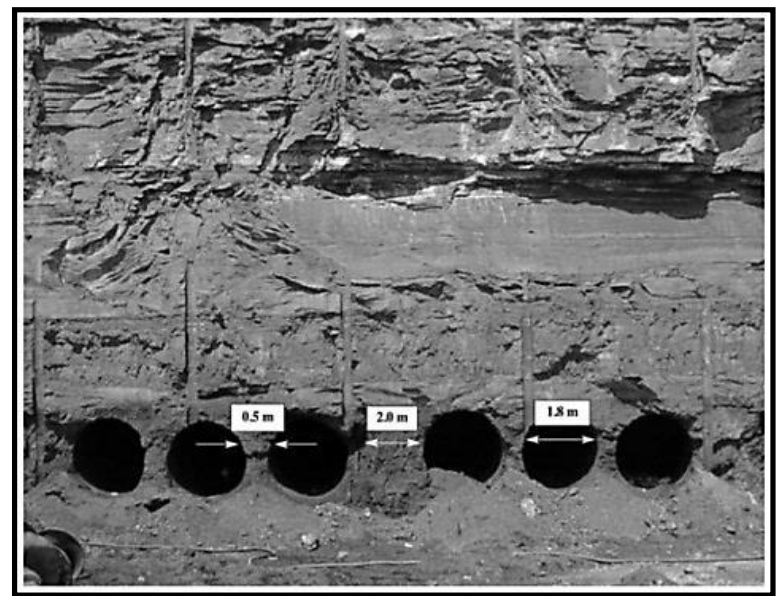

Gambar 5. Lubang bukaan penambangan gurdi di Rietspruit Mine Services (Pty) Ltd. (Lukhele, 2002) 


\section{Metode Elemen Hingga (Finite Element)}

Finite Element Method (FEM) merupakan pendekatan numerik persamaan diferensial parsial yang dapat memecahkan permasalahan fisika dan sains. FEM bekerja dengan cara membagi bidang yang akan dianalisis menjadi finite element, atau sering disebut elemen yang dihubungkan melalui nodal yang menghasilkan solusi. Metode ini biasa disebut sebagai finite element mesh, sedangkan proses pembuatan mesh tersebut disebut mesh generation (Fish dan Belytschko, 2007). Konsep dasar finite element analysis adalah mendiskretisasi atau membagi suatu struktur menjadi bagian-bagian yang lebih kecil yang jumlahnya berhingga (Gambar 6), kemudian menganalisis gabungan elemen-elemen kecil tersebut menjadi rangkaian yang bernilai. Finite Element Analysis (FEA) ini dikatakan bersifat computer oriented karena memerlukan perangkat computer untuk menyelesaikan formulasi persamaan tiap kasus. Program FEA yang berkembang pesat serta banyak digunakan untuk melakukan analisis struktur adalah perangkat lunak ansys (Awwaluddin dkk., 2013).

Apabila hasilnya belum mendekati hasil yang diharapkan, model dapat dibangun kembali dengan rangkaian mesh yang lebih halus (Gambar 7).

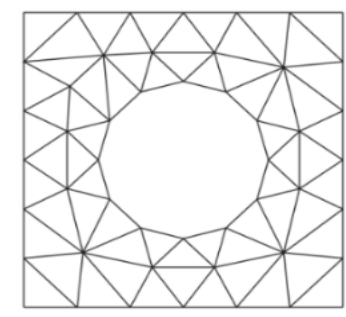

Gambar 6. Model Finite Element (Fish dan Belytschko, 2007)

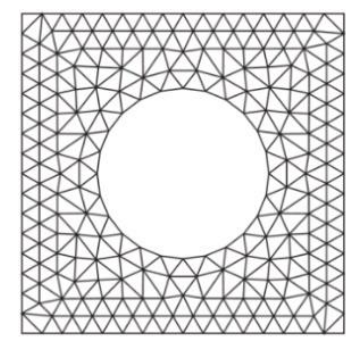

Gambar 7. Model Finite Element dengan Mesh yang halus (Fish dan Belytschko, 2007)

\section{Kestabilan Lereng dan Bukaan Tambang}

Kestabilan lereng dan batuan pada areal sekitar tambang adalah aspek penting untuk dikaji sebelum dilakukan penerapan penambangan dengan metode ini. Stabilitas lereng yang dinyatakan dengan faktor keamanan lereng (FK) adalah angka perbandingan kekuatan geser (shear strength) massa batuan yang dapat dikerahkan untuk menahan lereng agar tidak longsor dengan tegangan geser (shear stress) yang bekerja pada bidang longsor (bidang gelincir) karena gaya beratnya untuk mendorong lereng itu. Secara teoritis, FK $>1,0$ adalah stabil dan FK $<1,0$ adalah longsor dan tepat FK = 1,0 kondisi kritis. Dengan mempertimbangkan banyak faktor ketidak-pastian yang terjadi dalam membuat model lereng, input parameter geoteknik dan lain sebagainya, serta resiko yang akan dihadapi jika terjadi kelongsoran lereng, maka kriteria stabilitas yang umumnya digunakan pada tambang terbuka adalah $\mathrm{FK}=1,2-1,5$. Untuk lereng keseluruhan (overall pit slope) pada tambang skala besar, rekomendasi dari pengawas (regulator) adalah FK = 1,5 (Yadi, 2015). Dalam kondisi yang sangat ketat, ditinjau dari aspek keekonomian, jika ketersediaan data sangat komprehensif, representatif, dan didukung analisis yang cermat oleh tenaga ahli profesional, $\mathrm{FK}=1,2$ masih bisa diterima (Yadi, 2015).

\section{Tegangan Alamiah Batuan}

Kondisi kestabilan lereng sangat dipengaruhi oleh kondisi tegangan alamiah batuan yaitu tektonik, termal, gravitasi dan terinduksi (Rai, Kramadibrata dan Wattimena, 2012)

Tegangan Tektonik terjadi akibat geserangeseran pada kulit bumi yang terjadi pada waktu lampau sampai saat ini, seperti pada saat terjadi sesar dan lain-lain.

Tegangan Termal terjadi karena pemanasan atau pendinginan batuan dan terjadi di dekat permukaan yang terkena panas matahari atau sebagai hasil pemanasan bagian dalam bumi karena bahan-bahan radioaktif atau proses geologi lainnya.

Tegangan gravitasi terdiri dari tegangan vertikal dan horisontal. Tegangan vertikal 
batuan pada massa batuan sama dengan hasil dari kedalaman pada satuan berat massa batuan yang berada di atasnya. Tegangan ini dapat dihitung dengan persamaan $\sigma_{v}=\gamma z$. Dalam hal ini $\sigma_{v}$ adalah tegangan vertikal, $\gamma$ merupakan bobot isi batuan yang berada di atasnya $\left(\operatorname{ton} / \mathrm{m}^{3}\right)$; dan $\mathrm{z}$ adalah kedalaman batuan yang dihitung dari permukaan $(\mathrm{m})$.

Tegangan terinduksi adalah tegangan yang terjadi ketika lubang bukaan tambang digali ke dalam sebuah massa batuan, maka tekanan di sekitar lubang bukaan tersebut akan terdistribusikan kembali.

\section{Data Penampang dan Kondisi Lereng}

Penelitian ini mencakup wilayah yang terletak pada $1^{\circ} 50^{\prime} 00^{\prime \prime}-1^{\circ} 57^{\prime} 02^{\prime \prime}$ Lintang Selatan dan $115^{\circ} 51^{\prime} 00^{\prime \prime}-115^{\circ} 56^{\prime} 00^{\prime \prime}$ Bujur Timur. Secara administratif wilayah ini termasuk ke dalam Desa Batu Kajang, Kecamatan Batu Sopang, Kabupaten Paser, Provinsi Kalimantan Timur (Gambar 8).
Lokasi penampang $\mathrm{F}^{-\mathrm{F}^{\prime}}$ pada penelitian tebing batas ini berada pada sumuran (pit) A daerah Paser, Kalimantan Timur. Penampang F-F' ini terdiri dari penampang $1 \mathrm{~F} 1$ dan penampang 2 F2 (Gambar 9). Pada penelitian ini hanya diteliti untuk penampang $F-F^{\prime}$ pada penampang $1 \mathrm{~F} 1$. Stratigrafi lokal area pit A ini didominasi oleh batu lumpur abu-abu yang keras dan batupasir berwarna putih keabuabuan yang berbutir halus hingga sedang, masif keras dan sisipan batubara berwarna kecoklatan, kusam, keras, dan beberapa bagian menunjukkan struktur lignit. Dari hasil pemboran eksplorasi yang dilakukan dengan capaian kedalaman sampai 270 meter memberikan informasi sebagai berikut. Formasi di wilayah ini disusun oleh satuan batuan berupa batu lumpur (mudstone) yang berselingan dengan batupasir (sandstone) dengan sisipan-sisipan batubara. Ketebalan batubara pun bervariasi, mulai dari $<1.0 \mathrm{~m}$ hingga mencapai $18 \mathrm{~m}$. Pada penampang F-F' bagian 1 F1 terdapat 25 lapisan yang terdiri dari lapisan batu lumpur (warna hijau), batu pasir (warna kuning), batubara (warna merah), dan wastedump (warna coklat) pada bagian atas seperti terlihat pada Gambar 10.

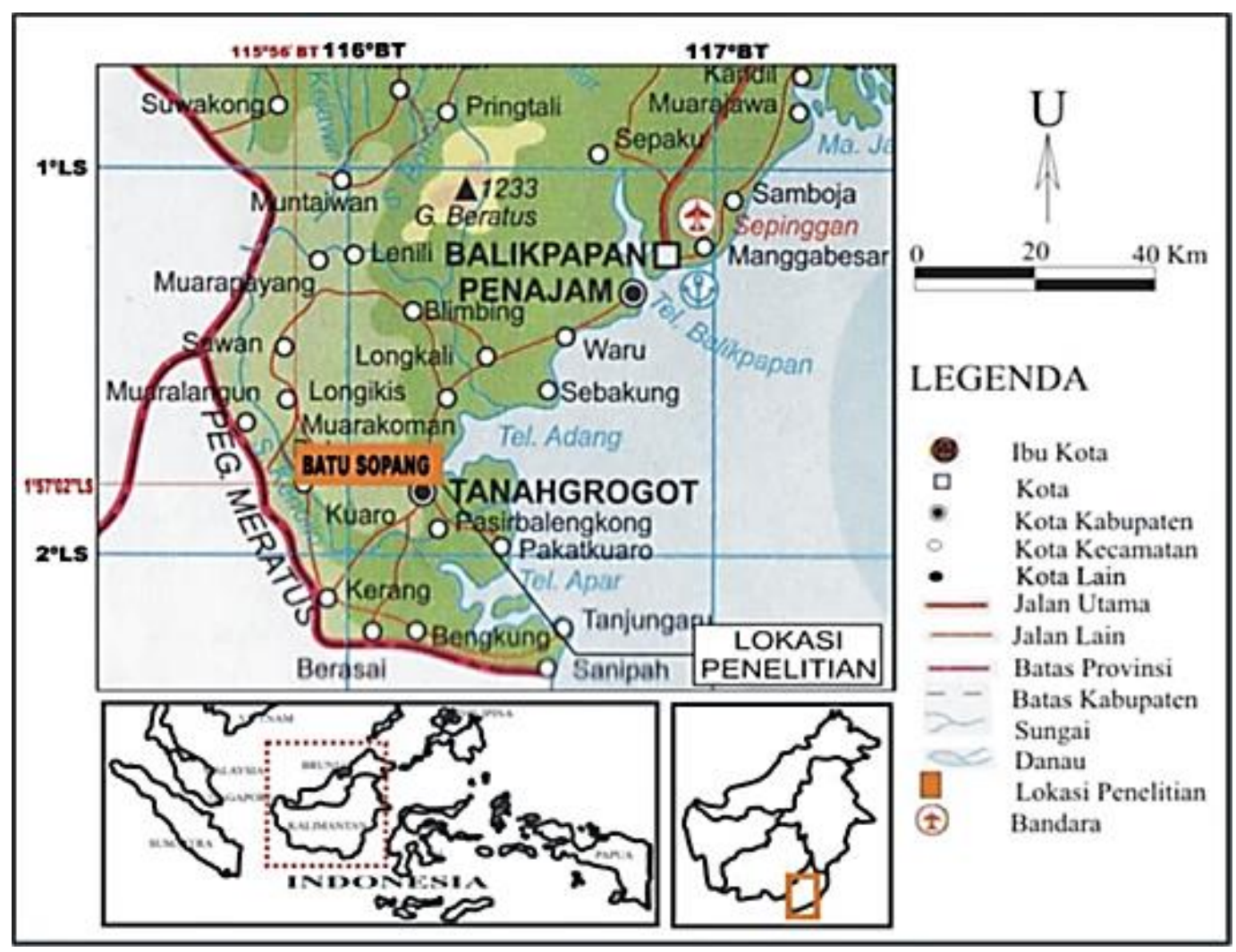

Gambar 8. Lokasi kesampaian Daerah Paser dan sekitarnya 


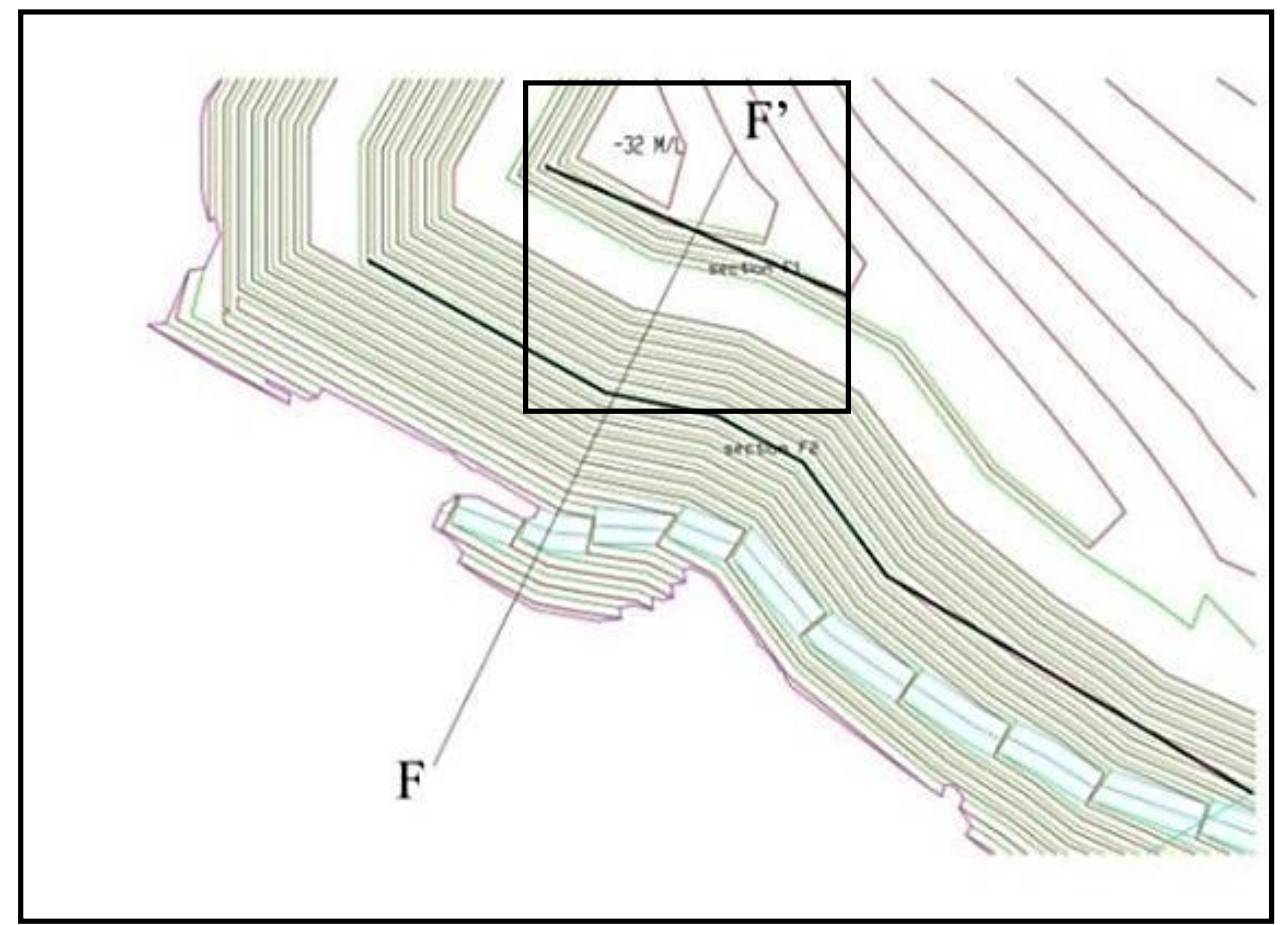

Gambar 9. Desain Section F-F'section F1

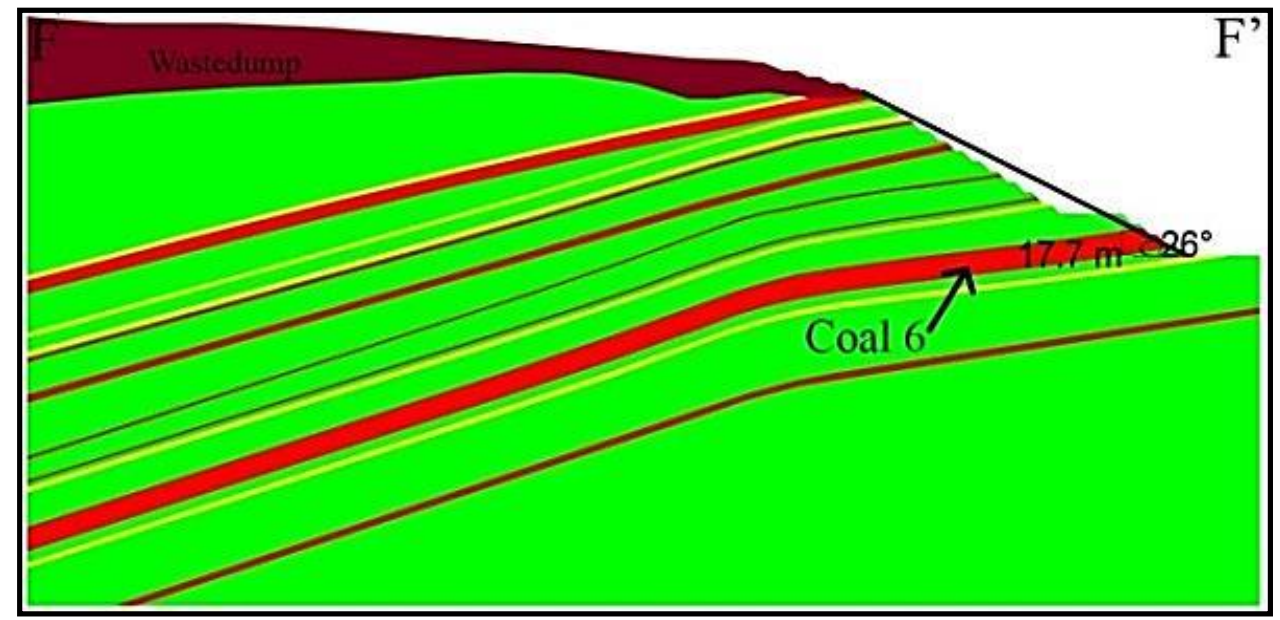

Gambar 10. Lapisan batuan section F-F' section F1

Parameter input data geoteknik batuan untuk pemodelan penampang $\mathrm{F}-\mathrm{F}^{\prime}$ bagian $1 \mathrm{~F} 1$ adalah sifat fisik dan mekanik batuan, yaitu data bobot isi asli (unit weight; $\gamma$ ), kuat tekan uniaksial (UCS; $\left.\sigma_{c}\right)$, modulus elastisitas (E), poisson's ratio $(v)$, kohesi puncak $\left(C_{p}\right)$, sudut gesek dalam puncak $\left(\phi_{\mathrm{p}}\right)$, kohesi residu $\left(\mathrm{C}_{\mathrm{r}}\right)$, sudut gesek dalam residu $\left(\phi_{r}\right)$, dan kuat tarik batuan (Tabel 1).
Seperti terlihat pada Gambar 8 penampang F$\mathrm{F}^{\prime}$ terdiri dari 25 lapisan material dengan data geoteknik berurutan pada Tabel 1, mulai dari yang paling atas (wastedump) hingga lapisan terakhir (mudstone12). Data ini akan dimasukkan ke perangkat lunak ansys sebagai engineering data. 
Tabel 1. Data geoteknik batuan penampang F-F'

\begin{tabular}{|c|c|c|c|c|c|c|c|c|c|c|}
\hline Lapisan & Material & $\begin{array}{l}\text { Bobot } \\
\text { Isi }\end{array}$ & $\begin{array}{l}\text { Kuat } \\
\text { Tekan }\end{array}$ & $\begin{array}{l}\text { Modulus } \\
\text { Elastisitas }\end{array}$ & $\begin{array}{l}\text { Poisson's } \\
\text { Ratio }\end{array}$ & $\begin{array}{l}\text { Kuat } \\
\text { Tarik }\end{array}$ & $\begin{array}{l}\text { Kohesi } \\
\text { Puncak }\end{array}$ & $\begin{array}{c}\text { Sudut } \\
\text { Geser } \\
\text { Puncak }\end{array}$ & $\begin{array}{l}\text { Kohesi } \\
\text { Residu }\end{array}$ & $\begin{array}{l}\text { Sudut } \\
\text { Geser } \\
\text { Residu }\end{array}$ \\
\hline & & $\mathrm{MN} / \mathrm{M}^{3}$ & Мpa & Mpa & - & Mpa & Mpa & 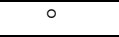 & Mpa & 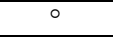 \\
\hline 1 & Batulumpur1 & 0,0217 & 2,2311 & 185,7767 & 0,3311 & 0,4900 & 0,3615 & 29,8809 & 0,0951 & 19,6773 \\
\hline 2 & Batubara1 & 0120 & 9,2667 & 857,5133 & 0,3433 & 1,4300 & 0,3684 & 29,9313 & 0,0976 & 19,6404 \\
\hline 3 & Batulumpur & 0217 & 2,2311 & 185,7767 & 0,3311 & 0,4900 & 0,3615 & 29,8809 & 51 & 19,6773 \\
\hline 4 & Batupasir1 & 0225 & 3,8957 & 521,7400 & 0,3200 & 0,2400 & 0,4506 & 30,5363 & 0,1280 & 19,1975 \\
\hline 5 & Batulumpur3 & 0217 & 2,2311 & 185,7767 & 0,3311 & 0,4900 & 0,3615 & 29,8809 & 0,0951 & 19,6773 \\
\hline 6 & Batubara2 & 0,0120 & 9,2667 & 857,5133 & 33 & 1,4300 & 0,3684 & 29,9313 & 0,0976 & 19,6404 \\
\hline 7 & Batulumpur4 & 0,0217 & 2,2311 & 185,7767 & 0,3311 & 0,4900 & 0,3615 & 29,8809 & 0,0951 & 19,6773 \\
\hline 8 & Batupasir2 & 0,0225 & 3,8957 & 521,7400 & & 0,2400 & & 30,5363 & & 19,1975 \\
\hline 9 & $\mathrm{Ba}$ & 7 & 2,2 & & 1 & 0,4 & 0 , & 29,8809 & & 19,6773 \\
\hline 10 & & & 9,2 & & & 1, & & 29,9313 & & 19,6404 \\
\hline 11 & Batulump & 0,0217 & 2,2311 & 185,7767 & 0,3311 & 0,4900 & 0,3615 & 29,8809 & & 19,6773 \\
\hline 12 & Batubara4 & 0,0120 & 9,2667 & 857,5133 & 0,3433 & 1,4300 & 0,3684 & 29,9313 & 0,0976 & 19,6404 \\
\hline 13 & Batulumpu & 0,0217 & 2,2311 & 185,7767 & 0,3311 & 0,4900 & & 29,8809 & & 19,6773 \\
\hline 14 & & & 9,2 & & & & & 29,9313 & & 19,6404 \\
\hline 15 & $\mathrm{Ba}$ & 7 & 2,2 & & 1 & 0, & & 29,8809 & & 19,6773 \\
\hline 16 & Batu & & 9,2 & & & 1,4 & & 29,9313 & & 19,6404 \\
\hline 17 & Batulumpur9 & 0,0217 & 2,2311 & 185,7767 & 0,3311 & 0,4900 & 0,3615 & 29,8809 & 0,0951 & 19,6773 \\
\hline 18 & Batupasir3 & 0,0225 & 3,8957 & 521,7400 & 0,3200 & 0,2400 & 0,4506 & 30,5363 & 0,1280 & 19,1975 \\
\hline 19 & Batulumpu & 0,0217 & 2,2311 & & & 0,4900 & & 29,8809 & & 19,6773 \\
\hline 20 & & & 3,8957 & & & & & 30,5363 & & 19,1975 \\
\hline 21 & Batul & 0,02 & 2,2311 & 1 & & 0,4 & & 29,8809 & & 19,6773 \\
\hline 22 & Batul & 0,0120 & 9,2667 & 857,5 & 33 & 1,4 & 0,3 & 29,9313 & & 19,6404 \\
\hline 23 & Batupasir5 & 0,0225 & 3,8957 & 521,7400 & 0,3200 & 0,2400 & 0,4506 & 30,5363 & 0,1280 & 19,1975 \\
\hline 24 & Batulumpur12 & 0,0217 & 2,2311 & 185,7767 & 0,3311 & 0,4900 & & 29,8809 & 0,0951 & 19,6773 \\
\hline 25 & $\begin{array}{l}\text { Penampung } \\
\text { Limbah }\end{array}$ & 0,0161 & & 1280,0000 & 0,2140 & 0,0680 & 0,1000 & 16,0000 & 0,0300 & 6,8000 \\
\hline
\end{tabular}

\section{HASIL DAN PEMBAHASAN}

\section{Pemodelan Penambangan Gurdi}

Pemodelan ini dirancang dengan lebar penampang $\mathrm{F}_{-} \mathrm{F}^{\prime}$ diketahui $295 \mathrm{~m}$, overall slope angle sebesar $26^{\circ}$, dan tebal batubara 17,7 m terdiri dari 25 lapisan. Untuk geometri dilakukan simulasi spasi antar panel sebesar 0,5 m, barrier pillar $3 \mathrm{~m}$, jumlah panel 5 , kemiringan bor penambangan gurdi sebesar $6^{\circ}$, serta untuk diamater pemotong kepala yang digunakan sebesar 1,8 m, yang dapat dilihat pada Gambar 11. Dalam kajian ini kedalaman bor penambangan gurdi dibuat bervariasi yaitu 50, 80, 120, dan $200 \mathrm{~m}$ (Gambar 12).
Perangkat lunak ansys sebagai perangkat lunak mendistribusi atau membaca data operasional sebagai parameter masukkan, maka terdapat proses mesh generation yang membagi model 3D dalam beberapa elemen (Gambar 13). Data operasional yang digunakan adalah tegangan vertikal $\left(\sigma_{\mathrm{v}}\right)$, tegangan horisontal $\left(\sigma_{h}\right)$, tegangan tangensial $\left(\sigma_{\circ}\right)$, kondisi suhu, dan faktor kegempaan. Nilai $\sigma_{\mathrm{v}}=\sigma_{\mathrm{h}}=\sigma_{\mathrm{o}}=\mathrm{\gamma H}(\mathrm{\gamma}=$ bobot isi batuan, $\mathrm{H}=$ kedalaman), dan $\sigma_{\theta}=2 \sigma_{\text {o }}$. Dengan menjalankan meshing dapat diketahui distribusi total deformasi dan distribusi faktor keamanan lereng (FK) dari setiap elemen (mesh) dari model. 


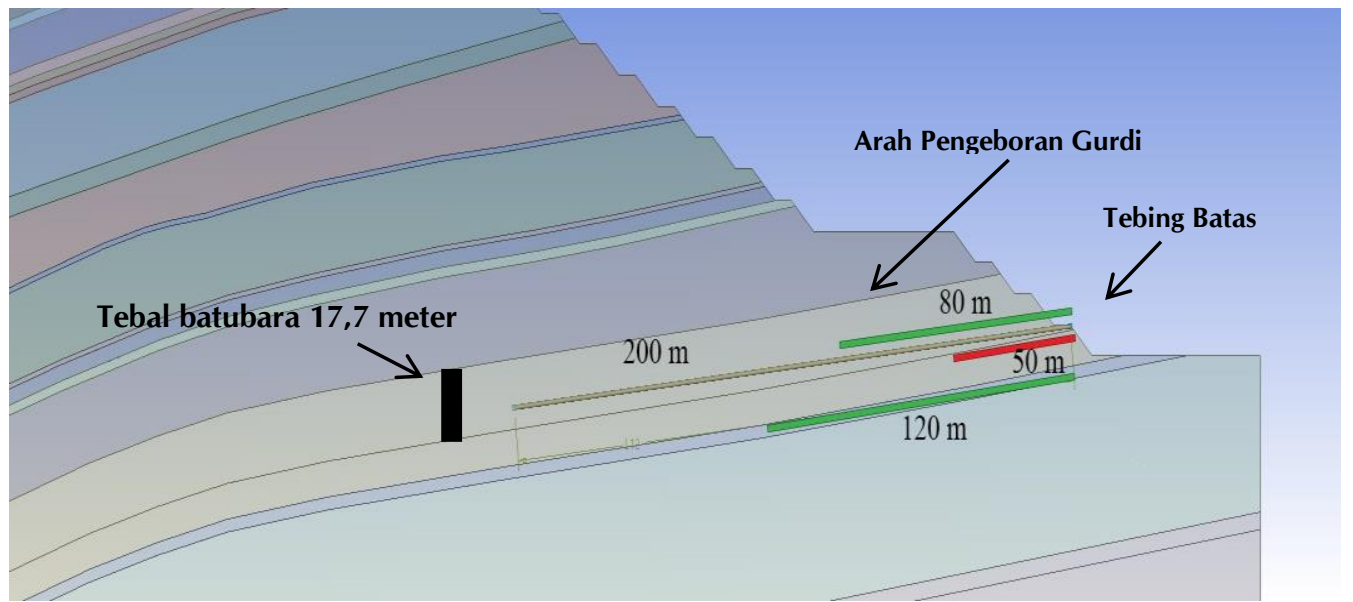

Gambar 11. Arah kemiringan bor gurdi

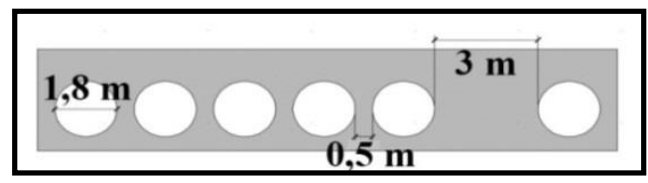

Gambar 12. Simulasi desain penambangan gurdi

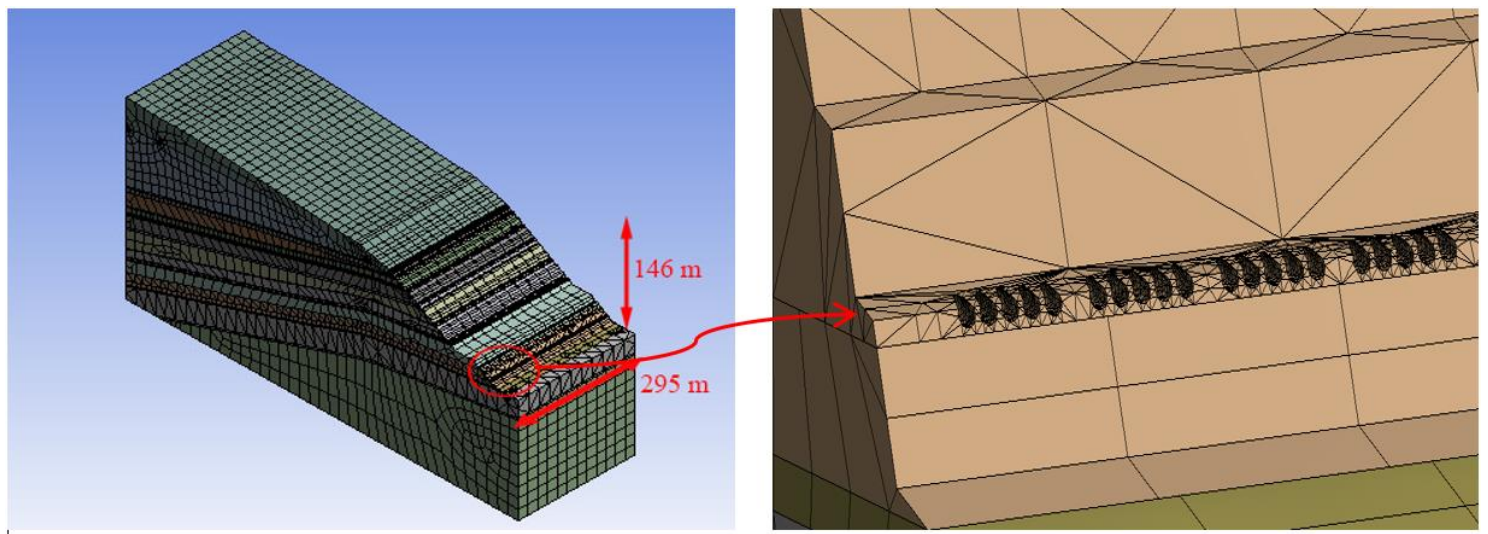

Gambar 13. Model elemen hingga dengan mesh pada lubang bukaan batubara penambangan gurdi

\section{Faktor Keamanan}

Secara teoritis nilai FK $\geq 1$ menunjukkan nilai lereng yang aman. Nilai faktor keamanan ini menunjukkan angka yang menggambarkan besarnya nilai kekuatan batuan penahan dibandingkan dengan nilai gaya pendorong batuan yang bekerja pada setiap elemen model, sesuai dengan kriteria keruntuhan yang digunakan. Namun dalam penelitian ini, ditetapkan nilai FK $\geq 1,5$ merupakan nilai yang menunjukkan kriteria yang aman dan ideal untuk diterapkannya penambangan gurdi pada tebing batas penampang $\mathrm{F}-\mathrm{F}^{\prime}$ ini. Faktor keamanan yang dihasilkan pada tebing batas dengan variasi kedalaman lubang bukaan penambangan gurdi dapat dilihat pada Gambar 14. 


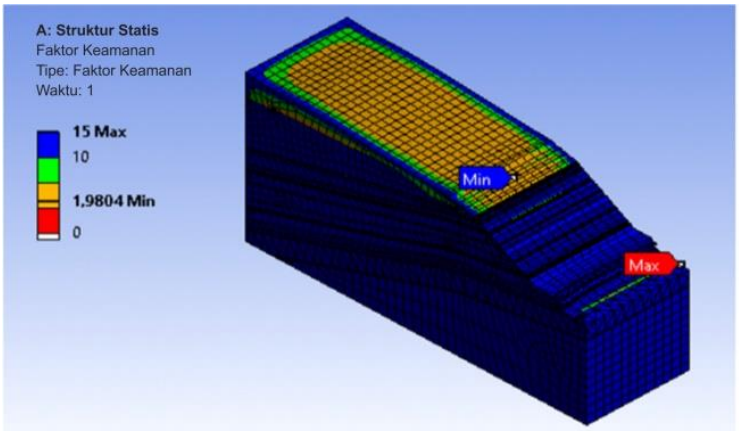

(a)

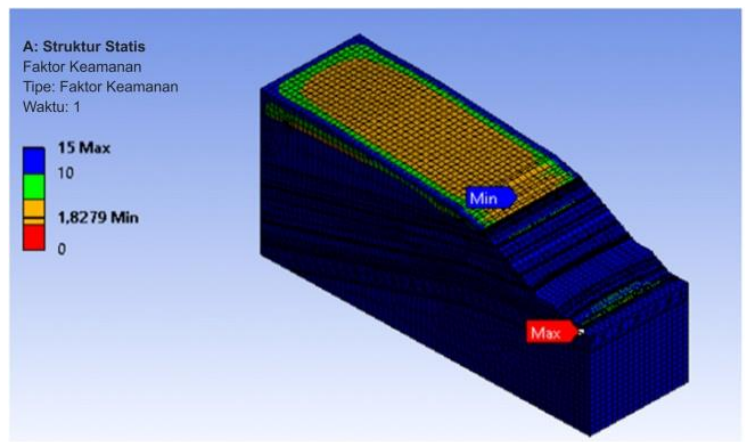

(c)

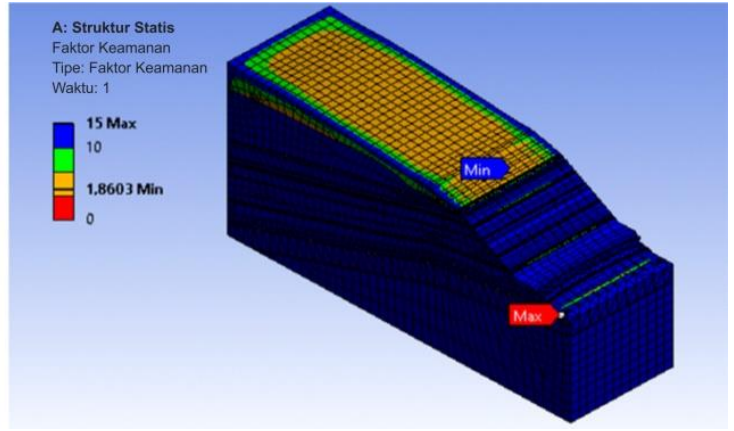

(b)

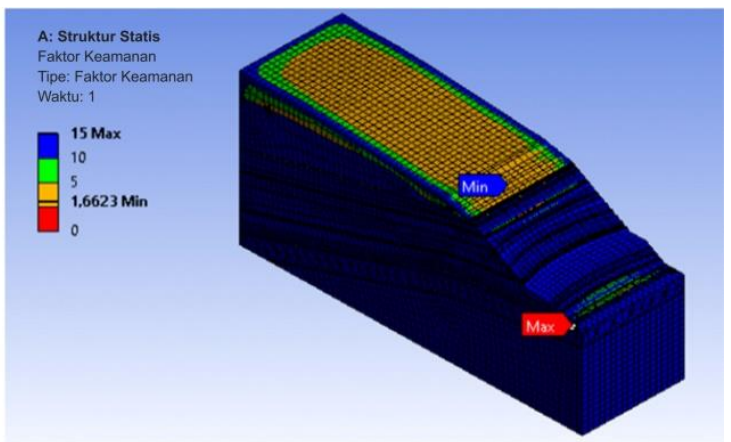

(d)

Gambar 14. Variasi faktor keamanan (FK) berdasarkan variasi kedalaman: $50 \mathrm{~m}$ (a), $80 \mathrm{~m}$ (b), $120 \mathrm{~m}$ (c) dan $200 \mathrm{~m}$ (d)

\section{Total Deformasi}

Total deformasi menunjukkan perubahan bentuk atau geometri akibat pembebanan atau gaya dari luar yang diberi pada saat lubang gurdi telah dibuat. Berikut adalah hasil analisis total deformasi penambangan gurdi dengan simulasi variasi kedalaman yang ditunjukkan pada Gambar 15.

Dari hasil output faktor keamanan dan total deformasi yang telah dilakukan maka dapat dirangkum nilainya yang disajikan pada Tabel 2. Tabel 2 menunjukkan nilai FK $>1,5$ maka lereng dinyatakan aman untuk penerapan metode penambangan gurdi. Simulasi yang dilakukan pada kedalaman 50, 80, 120, dan
$200 \mathrm{~m}$, besarnya total deformasi dapat dilihat pada Gambar 13. Hasil analisis deformasi tersebut menunjukkan kondisi nilai deformasi atau besar perubahan lereng yang sangat kecil, maka lereng tebing batas dapat dinyatakan aman untuk penerapan metode penambangan gurdi.

Nilai deformasi pada kedalaman $80 \mathrm{~m}$ lebih kecil dari pada nilai deformasi pada kedalaman $50 \mathrm{~m}$. Hal ini dikarenakan kedalaman $80 \mathrm{~m}$ berada tepat di bawah jalur angkut yang salah satunya berfungsi untuk menstabilkan lereng tebing batas. Kedalaman $80 \mathrm{~m}$ memiliki batuan penyangga yang lebih besar dari pada kedalaman $50 \mathrm{~m}$. 


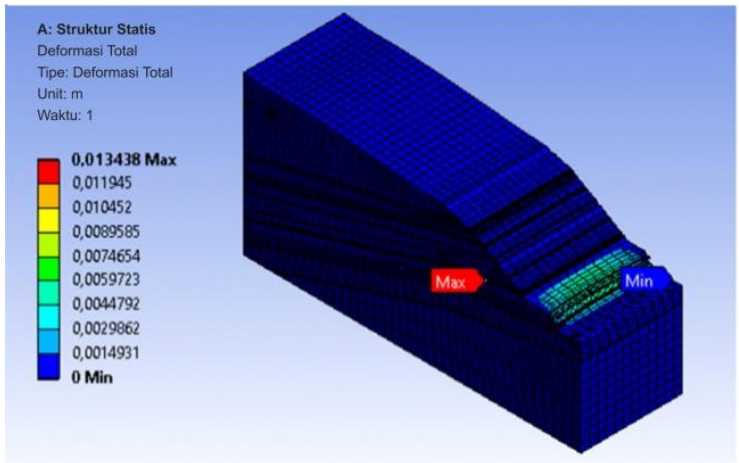

(a)

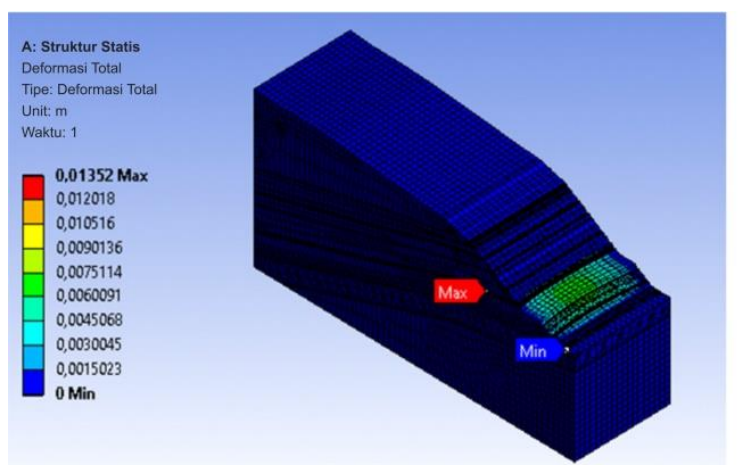

(c)

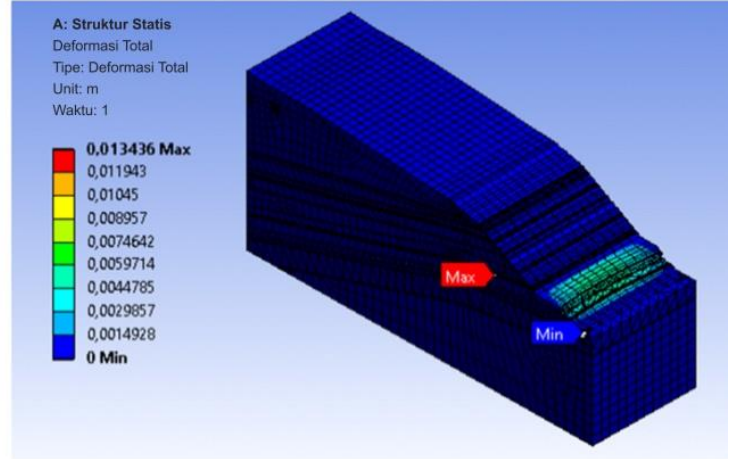

(b)

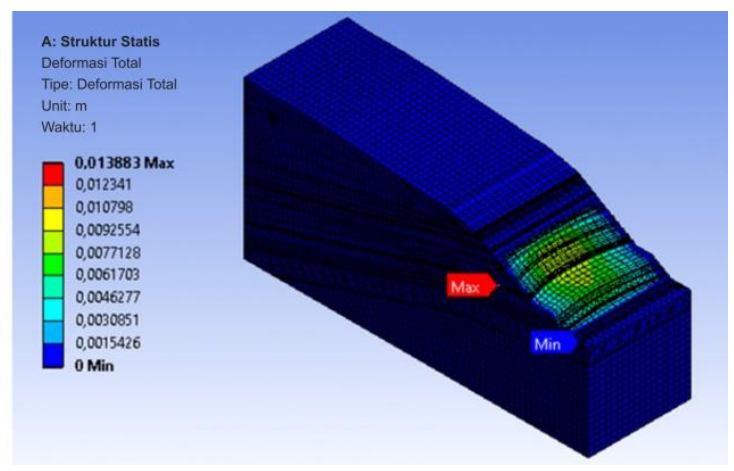

(d)

Gambar 15. Total deformasi pada berbagai variasi kedalaman: 50 m (a), 80 m (b), 120 m (c) dan 200 m (d)

Tabel 2. Rangkuman hasil analisis FK dan total deformasi pada variasi kedalaman lubang gurdi

\begin{tabular}{ccccc}
\hline No. & Kedalaman Bor $(\mathrm{m})$ & FK & Total Deformasi $(\mathrm{m})$ & Keterangan \\
\hline 1 & 50 & 1,9804 & 0,013438 & Aman \\
2 & 80 & 1,8603 & 0,013436 & Aman \\
3 & 120 & 1,8279 & 0,013520 & Aman \\
4 & 200 & 1,6623 & 0,013883 & Aman \\
\hline
\end{tabular}

\section{KESIMPULAN DAN SARAN}

Geometri penambangan gurdi yang stabil pada penelitian ini adalah spasi antar panel sebesar 0,5 m, barrier pillar $3 \mathrm{~m}$, jumlah panel 5, dan kemiringan bor penambangan gurdi sebesar $6^{\circ}$ menggunakan diameter bor auger cutter head 1,8 m.

Simulasi kedalaman yang dilakukan pada tebing batas menunjukkan nilai faktor keamanan yang stabil. Pada kedalaman $50 \mathrm{~m}$ nilai faktor keamanannya sebesar 1,9804, dan pada kedalaman $80 \mathrm{~m}$ nilai faktor keamanannya sebesar 1,8603 sedangkan pada kedalaman $120 \mathrm{~m}$ nilai faktor keamanannya sebesar 1,8279 serta pada kedalaman 200 m nilai faktor keamanannya sebesar 1,6623.

Simulasi kedalaman yang dilakukan pada tebing batas menunjukkan nilai total deformasi untuk kedalaman $50 \mathrm{~m}$ sebesar $0,013438 \mathrm{~m}$. Pada kedalaman $80 \mathrm{~m}$ total deformasi maksimal sebesar 0,013436 m, sedangkan pada kedalaman $120 \mathrm{~m}$ total deformasi maksimal sebesar 0,013520 m, dan pada kedalaman $200 \mathrm{~m}$ total deformasi maksimal sebesar 0,013883 m.

Hasil kajian menunjukkan bahwa daerah penelitian dapat dilakukan penerapan metode penambangan gurdi dengan geometri yang telah dirancang. 


\section{UCAPAN TERIMA KASIH}

Ucapan terima kasih ditujukan kepada Puslitbang Teknologi Mineral dan Batubara (tekMIRA) dan Jurusan Teknik Pertambangan Fakultas Teknik Universitas Sriwijaya yang telah memberikan kesempatan dan menyediakan fasilitas kepada Penulis untuk melakukan penelitian ini.

\section{DAFTAR PUSTAKA}

Awwaluddin, M., Purwanta, E., Prijono, K., Priyono and Praptoyo, S. (2013) 'Analisis statik rangka pemegang perisai radiasi pada alat scintigraphy menggunakan software ANSYS', Jurnal Perangkat Nuklir, 7(1), pp. 12-22. Available at:

http://jurnal.batan.go.id/index.php/jpn/article/vi ew/393.

Caterpillar (2009) A reference guide to mining language - Field guide 2009. Caterpillar.

Direktorat Jenderal Mineral dan Batubara (2017) Laporan kinerja 2016. Jakarta. Available at: https://www.minerba.esdm.go.id/library/publi sh/LAKIN MINERBA 2016.pdf.

Dougall, A. W. (2010) A review of the current and expected underground coal mining methods and profiles and an evaluation of the best practices associated with these. University of the Witwatersrand, Johanesburg. Available at: https://www.researchgate.net/publication/275 524737 A review of the current and expec ted_underground_coal_mining_methods_and _profiles_and_an_evaluation_of_the_best_pra ctices_associated_with_these.

Fish, J. and Belytschko, T. (2007) A first course in finite elements. 1st Ed. New York: Wiley.

Lin, N. Z. (2014) Mining system and design for development of underground coal mine form open-cut highwall for thick coal seam. Kyushu University Fakuoka. Available at: https://catalog.lib.kyushuu.ac.jp/opac_download_md/1441219/eng233 1.pdf.
Lukhele, M. J. (2002) 'Surface augur mining at Rietspruit Mine Services (Pty) Ltd', Journal of the Southern African Institute of Mining and Metallurgy, 102(2), pp. 115-119. Available at:

https://journals.co.za/content/saimm/102/2/AJ A0038223X_2782.

Porathur, J. L., Roy, P. P., Shen, B. and Karekal, S. (2017) Highwall mining: Applicability, design \& safety. 1st Ed. CRC Press.

Rai, M. A., Kramadibrata, S. and Wattimena, R. K. (2012) Mekanika batuan. Bandung: ITB Press.

Sasaoka, T., Hamanaka, A., Shimada, H., Matsui, K., Lin, N. Z. and Sulistianto, B. (2015) 'Punch multi-slice longwall mining system for thick coal seam under weak geological conditions', Journal of Geological Resource and Engineering, 4(1), pp. 28-36. doi: 10.17265/2328-2193/2015.01.004.

Sasaoka, T., Shimada, H., Hamanaka, A., Sulistianto, B., Ichinose, M. and Matsui, K. (2015) 'Geotechnical issues on application of highwall mining system in Indonesia', in ISRM VietRock International Workshop. Hanoi: International Society for Rock Mechanics and Rock Engineering, p. 3/12/153/13/15. Available at: https://kyushuu.pure.elsevier.com/en/publications/geotechn ical-issues-on-application-of-highwall-miningsystem-inin.

Swana, G. W., Muslim, D. and Sophian, I. (2012) 'Disain lereng dengan metode RMR, SMR, dan analisis kestabilan lereng pada tambang batubara terbuka, di Kabupaten Tanah Laut, Provinsi Kalimantan Selatan', Buletin Sumber Daya Geologi, 7(2), pp. 92-108. Available at: http://buletinsdg.geologi.esdm.go.id/index.ph p/bsdg/article/view/BSDG_VOL_7_NO_2_20 12_5.

Yadi, Z. (2015) 'Kestabilan geometri lereng bukaan tambang batubara di PT. Pasific Global Utama Kabupaten Muara Enim, Provinsi Sumatera Selatan', in Prosiding Teknik Pertambangan. Bandung: Universitas Islam Bandung, pp. 1-8. Available at: http://karyailmiah.unisba.ac.id/index.php/pert ambangan/article/viewFile/1094/pdf. 